THE USE OF KOREAN WORDS BY NON-NATIVE SPEAKERS IN STIKES BANYUWANGI

\author{
Written by: \\ Wahyu Adri Wirawati \\ Midwivery Diploma Three Study Program \\ STIKES Banyuwangi \\ wahyuadriwirawati2@gmail.com
}

\begin{abstract}
Korean language has become one of the famous foreign languages in Indonesia. It entered Indonesia through their culture such as songs, movies and dramas. Indonesia people, in this study the students of STIKES Banyuwangi, learn the Korean language through subtitles given in every movie and drama, and also lyrics of a song. The subtitles are usually written in English or in bahasa Indonesia, while the lyrics of a song usually written in English, Hangul (Korean alphabet) and Korean language written in Latin alphabet. Using the subtitles and the lyrics, the Indonesia people can learn and use the Korean language. Nevertheless, their Korean language is not used appropriately because they do not understand the whole meaning of a conversation and the grammar and strucure of a sentence so they only use several words that have specific meaning. They acquire the words that usually appear in the subtitles and try to translate it into Bahasa Indonesia by using 'Google Translate' or dictionary. Most of the words are related to feeling and nickname in relationship. Yet, because there is still little number of people understanding Korean language, the Indonesian teenagers only use it with their peer who also like the Korean culture. They do not use it in a formal situation or in a situation when they know the person they speak to does not understand Korean language. When they speak in Korean language, code mixing appears. Entertainers, particularly singer, actor and actress, become the major factor that motivates the students to learn Korean language. It has influenced the students in STIKES Banyuwangi and as a result several of them use Korean words in their communication.
\end{abstract}

Keywords: Korean language, words, language learning.

\title{
Introduction
}

Nowadays, Korean language becomes a famous foreign language in Indonesia. It was started when songs, movies and dramas from Korea entered the television segment in Indonesia. As the result, many teenagers and young adults use some Korean words to show that they like the Korean style. Therefore, the use of Korean words among the teenagers and young adult become a phenomenon in linguistics field and interest the writer to investigate the phenomenon.

The study that will be used to analyze the phenomenon is psycholinguistics. According to Chaer (2003: 16), psycholinguistics is a branch of linguistics which learns the relation between language and human's behavior and intelligence, including how a language is acquired. Wiśniewski (2007) propose that psycholinguistics is concerned with the relationship between the human mind and the language as it examines the processes that occur in brain while producing and perceiving both 
written and spoken discourse. Thus, how Korean language is learned and used by the teenagers and young adult, especially by the students of STIKES Banyuwangi, is interesting to investigate.

From the investigation, there will appear several hypotheses that can be served. First, the acquisition of the Korean words undergone by the students is by comparing the sound of the Korean words with the subtitle given in the songs or the dramas. The subtitle, then, is translated into Indonesian language by using dictionary. The second, the students use the Korean words in their daily conversation only with their peers who also know the meaning of the words or like the Korean style. The last, the reason they use it is because they like Korean entertainers.

Because this paper is discusses acquisition of Korean words by the students of STIKES Banyuwangi, it will discuss the data collection, the way of acquisition undergone by the students, the use of Korean words by the students, and the reason that motivates the students to learn Korean Language.

\section{The Data Collection}

The data was collected in the female dormitory of STIKES Banyuwangi where many students of STIKES Banyuwangi stay. The students are previously observed in order to get some qualified respondents. Then, ten respondents are chosen as the source of data. The next step is making questionnaire as a tool to get the data and distribute it to the respondents. The fourth step is analyzing the questionnaire and the last is writing the essay that reports the analysis.

\section{The Way of Acquisition}

Language acquisition and language learning are two terms used in psycholinguistics field. Chaer (2009: 167) proposes language acquisition as a process which takes place in a child's brain when he acquires his first language and language learning as a processes that happen when a child learns second language, after he acquires his first language. The term of language acquisition is also often used to represent the language learning. In Indonesia, Indonesian language and Javanese are the first language acquired by the children. After Korean culture has entered Indonesia, its language starts to be studied by the Indonesian, especially the teenagers. The Korean language is acquired and learned after the teenagers acquire their first language, thus, the Korean language becomes the second language. According to Saville-Troike (2006: 2), the second language (L2) may actually be the third, fourth, or tenth to be acquired.

The students of STIKES Banyuwangi, in this case as the non-native speaker, learn Korean Language from the Korean drama, song and movies. Therefore, the learning of Korean language doesn't take place in class. Saville-Troike (2006: 2) suggests that L2 learning that takes place in naturalistic contexts is called informal L2 learning. In addition, Chaer (2009: 243) states that the informal L2 learning is natural, without any teacher and unintentionally. Because it is not learned in a 
formal situation, the students only acquire the spoken language without really understanding the grammar of the language and they only learn some words and their meaning in Indonesia. Fromkin, Rodman and Hyams (2003, 379) suggests that adult second-language learners do not achieve nativelike grammatical competence in the L2, especially with respect to pronunciation. Skehan in Han (2004: 33) highlights L2 learners' natural inclination to focus on meaning, not on form. For the adult learners, meaning is more important than the form of the language.

One of medium of learning Korean language is song. Most of the Korean song that is interesting the students to listen to is brought by boy bands and girl bands and most of it talks about love. If the song is easy to listen and is interesting the student, they will try to get the lyric of the song. Some lyrics are written in Hangul (Korean alphabet), some are Korean language yet written in Latin alphabet and the others are written in English translation. The easiest way to learn Korean language is from the translation of the lyric in English. They used dictionary or Google Translate to translate the lyrics from English into Indonesian language. After they get the translation in Indonesia, they translate it into Korean language hereafter they understand the meaning of the word.

A similar way is undergone in Korean drama and movie. Korean Drama and movie are other mediums of learning Korean language. Usually, the subtitle of Korean drama and movie are in English, but many of them now are written in Indonesian language. In this case, the Indonesia subtitle is easier to understand than the English subtitle. If the subtitle is in English, the students use dictionary or Google Translate to translate it into Indonesia. After they understand the meaning in Indonesian language, they translate it into Korean.

Among the students, the user of Google Translate is bigger in number than the user of dictionary because of the easiness of the usage of Google Translate. They just have to choose the source language and the target language, type the words in the box, and click the translate icon, and then the Google Translate will translate the word typed into the target language.

Unfortunately, some words that are translated in Korean language are different from the words spoken in the drama and movie or sung in the song. When this happens, they compare the sound of the Korean words and its context with the translation in Indonesia. From this way, they can understand the meaning of the Korean language.

\section{The Use of Korean Words}

Most of the words that are used by the students state feeling and nickname in relationship. The words that are used when they try to show their feeling are sarang (love), bogoshipeo (miss), gwenchana (fine), miane (sorry), haengbokhae (happy), chuahe (like), shireo (don't want to), aigoo (ouch), omo (oh my God). The words related to the relationship are namely yeoja (woman), namja (man), appa (father), omma (mother), ahjussi (uncle, a name for an adult man), ahjumma (aunty, a name for an adult woman), dongsaeng (little brother/sister), oppa (older brother), unni (older sister), 
saram (person). These words are used when they call each other, such as unni, and when they talk about someone. While the other words are also often used by the students, such as babo (stupid), yoboseyo (say 'hello' in the phone), molla (do not know), ya (hey), annyeonghaseyo (hallo), annyeong (hey), ye (yes), andwe (don't).

These words are usually used when the students talk to their friends in informal situation. When they talk in the classroom with their lecturers, they do not use the Korean words. They usually use them in their daily conversation in the dormitory. In this situation, code mixing appears. According to Kridalaksana (2011: 40), code mixing refers to the use of language unit from one language to another language in order to broaden language style. Holmes (1992: 41) proposes that people sometimes switch code within a domain or social situation. The words are often mixed with Indonesian words. But, only one or two words appear in a sentence. Below is the example:

Putri : Unni, pintunya 'ku buka ya! (Sis, I'll open the door!)

Dilla : Jangan! Aku masih pake baju. (Don't! I'm still wearing my clothes.)

Putri : : Ku buka. 'Ku buka. (I'll open it. I'll open it.)

Dilla : Jangan! Put, andwe! Andwe! Andwe! (Don't! Put, don't! Don't! Don't!)

Such kind of conversation does not appear when the speaker know that the listener do not understand or do not like Korean style. They assumed that only those who like Korean style will understand Korean words. Therefore, when they talk to others considered do not like or understand Korean style, they only used Indonesian language. They also do not use Korean words when they talk to the older person. They prefer to use Indonesia language rather than Korean words because they think it is more polite.

\section{The Reason of the Use of Korean Language}

The Korean culture gives great influence to the teenager in Indonesia. The way of dressing, the way of using make up and the song are the most popular Korean culture in Indonesia teenager. The influence is especially got from the song, drama and movie. The data shows that all students who like the Korean songs, dramas and movies tend to use Korean words. Their motivation in learning Korean words is because they like the Korean singer, actor or actress. Even, they learn Korean language because they wish they can meet their idol.

Other reason is because someday they want to visit Korea. They want to learn more and enjoy Korean culture, history and people directly from the country itself. The last reason is because they wish someday they can study and work at that country. The Korean government gives several scholarships to the students in Indonesia to study in Korea. This opportunity will not be wasted by the students. Moreover, Korea becomes a developed country. Its economical condition has increased. Thus, it attracts the Indonesian students to work there. 


\section{Conclusion}

Korean language is a foreign language for Indonesian people and it is learned by the teenagers in Indonesia. They learn the Korean language from the lyrics of the Korean songs and subtitle in the movie and drama. Google Translate is a tool most frequently used by the students to translate the Korean word into Indonesian language so that they can use many words in their daily conversation. In the use of the Korean words, code mixing appears because the Korean words are mixed with Indonesian sentence. Nevertheless, only one or two words are used in it. Moreover, the Korean words are only used in informal situation and with their peer. It is considered to the listener, whether they like and understand about Korean style and words. The singer, actor and actress has great influence to the students to learn Korean language. Other factors are the scholarship given by the Korean government and the working opportunity in Korea.

\section{REFERENCES}

Chaer, Abdul. 2009. Psikolinguistik: Kajian Teoretik. Jakarta: PT. Rineka Cipta.

Holmes, Janet. 1992. An Introduction to Sociolinguistics. Essex: Longman Group Uk Limited.

Kridalaksana, Harimurti. 2011. Kamus Linguistik Edisi Keempat. Jakarta: PT. Gramedia Pustaka Utama.

Saville-Troike, Muriel. 2006. Introducing Second Language Acquisition. Cambridge: Cambridge University Press.

Fromkin, Victoria, Rodman, Robert and Hyams, Nina. 2003. An Introduction to Language: Seventh Edition. Massachusetts: Wadsworth. URL: http://library.nu/docs/31QFAMP76J/AnIntroductiontoLanguage(7th edition) Accessed on December, $24^{\text {th }}, 2011$

Han, Zhaohong. 2004. Fossilization in Adult Second Language Acquisition. Clevedon: Multilingual Matters Ltd. URL: http://library.nu/docs/WZRAJ80D5F/FossilizationinAdultSecondLanguageAcquisitionSecon dLanguageAcquisitionBuffalo\%2CN.Y.\%2C5. Accessed on December, $24^{\text {th }}, 2011$

Wiśniewski, Kamil. 2007. Psycholinguistics. URL: http://www.tlumaczeniaangielski.info/linguistics/psycholinguistics.htm. Accessed on October, $15^{\text {th }}, 2011$ 